\title{
Problem Based Learning (PBL) : Suatu Model Pembelajaran Untuk Mengembangkan Cara Berpikir Kritis Peserta Didik
}

\author{
IGA Mas Darwati \\ Universitas Dwijendra \\ masdarwati@undwi.ac.id
}

I Made Purana

Universitas Dwijendra purana@undwi.ac.id

\begin{abstract}
ABSTRAK
Pendidikan pada hakekatnya merupakan syarat mutlak bagi pengembangan sumber daya manusia dalam menuju masa depan yang lebih baik. Ketrampilan abad 21 menitikberatkan kepada kemampuan untuk berpikir kritis, menyelesaikan masalah, komunikasi, dan kerjasama yang merupakan bagian dari HOTS (High Order Thinking Skills) atau kemampuan berpikir tingkat tinggi yang sangat perlu dimiliki oleh peserta didik sebagai bekal dalam menghadapi tantangan global. Problem Based Learning (PBL) merupakan salah satu model pembelajaran yang menuntut aktivitas mental peserta didik untuk memahami suatu konsep pembelajaran melalui situasi dan masalah yang disajikan. Melalui PBL siswa dapat mengembangkan kemampuan yang dimiliki. Kemampuan yang dimaksud diantaranya berpikir kritis, inovatif, dan kreatif. Ketika PBL berlangsung, peserta didik dituntut untuk mampu menyelesaikan masalah sendiri dan bekerja mandiri, sehingga peserta didik dapat mengembangkan berpikir kritisnya. Peserta didik dapat dilatih mengembangkan ketrampilan berpikir tingkat tinggi dan pola berpikir kreatif.
\end{abstract}

Kata Kunci: PBL, Model Pembelajaran, Berpikir Kritis

\section{ABSTRACT}

Education is essentially an absolute prerequisite for human resource development towards a better future. 21st century skills emphasize the ability to think critically, solve problems, communicate, and collaborate which are part of HOTS (High Order Thinking Skills) or high-order thinking skills that are essential for students to have as a provision for facing global challenges. Problem Based Learning (PBL) is a learning model that requires mental activity of students to understand a learning concept through the situations and problems presented. Through PBL students can develop their abilities. The abilities referred to include critical, innovative, and creative thinking. When PBL takes place, students are required to be able to solve problems on their own and work independently, so that students can develop critical thinking. Students can be trained to develop higher order thinking skills and creative thinking patterns.

Key Word: PBL, Learning Model, Kritikal Thingking

\section{A. Pendahuluan}

Pendidikan adalah syarat mutlak bagi pengembangan sumber daya manusia dalam menuju masa depan yang lebih baik (Santika, 2017). Melalui pendidikan dapat dibentuk manusia yang mampu membangun dirinya sendiri, bangsa dan negaranya, maka dari itu diperlukan suatu usaha dalam meningkatkan kualitas dan mutu pendidikan. Perkembangan abad 21 menuntut peserta didik memiliki kompetensi antara lain memiliki kemampuan berpikir kritis dan kemampuan memecahkan masalah (critical thinking and problem solving skills), kemampuan literasi teknologi informasi dan komunikasi (information and communication technology skills), dan kemampuan informasi dan literasi media (information and media literacy skills), dan kemampuan belajar kontekstual (contextual learning skills). Pada dasarnya hal ini menitikberatkan kepada kemampuan untuk berpikir kritis, menyelesaikan masalah, komunikasi dan kerjasama yang merupakan bagian dari High Order Thinking Skills (HOTS). 
Permasalahan yang dihadapi dalam dunia pendidikan saat ini sangatlah kompleks dan beragam. Mulai dari lemahnya dalam proses pembelajaran dan evaluasi pembelajaran. Dalam proses pembelajaran, lemahnya daya dukung kepada peserta didik untuk mampu mengembangkan ketrampilan berpikir akan tetapi dipaksa untuk menghafalkan suatu informasi. Pendidikan di sekolah selalu menjejali peserta didik dengan teori yang harus dihafal dan mengingat informasi tanpa diarahkan untuk menghubungkan dengan kehidupan sehari-hari, sehingga peserta didik hanya memiliki pemahaman teoritis yang miskin aplikasi (Santika, 2020).

Proses pembelajaran tidak hanya untuk meningkatkan pengetahuan, tetapi harus dilengkapi dengan pengembangan kemampuan kreatif dan berpikir kritis, berkarakter kuat, dan didukung dengan kemampuan yang memanfaatkan informasi dan komunikasi. Hal ini sangat diperlukan dimiliki oleh peserta didik sebagai bekal dalam menghadapi berbagai macam tantangan di era globalisasi yang semakin kompleks. Pembelajaran adalah suatu proses interaksi antara guru dan peserta didik beserta unsur di dalamnya. Dosen/guru adalah faktor utama yang menentukan kualitas pembelajaran. Kualitas pembelajaran yang baik akan menghasilkan hasil belajar yang baik pula. Salah satu tuntutan dosen/guru tersebut adalah mampu memilih metode pembelajaran yang tepat, sehingga tujuan pembelajaran akan lebih mudah dicapai, meningkatkan minat dan motivasi belajar peserta didik, dan tercipta suasana pembelajaran yang menyenangkan.

Melihat kondisi dunia pendidikan saat ini sangat membutuhkan penerus generasi muda yang cakap dan kritis, peserta didik yang tidak hanya dituntut menyelesaikan tugas atau nilai yang baik, akan tetapi peserta didik juga dituntut memilik kemampuan berpikir kritis. Oleh karena itu dibutuhkan model pembelajaran yang berorientasi pada peserta didik, sehingga mampu mengembangkan kemampuan berpikir kritis dan memecahkan masalah yang dihadapi dalam kehidupan sehari-hari. Problem Based Learning (PBL) merupakan salah satu model pembelajaran yang dapat diterapkan karena mendorong peserta didik untuk berpikir kritis, terampil menyelesaikan masalah, menghubungkan pengetahuan mengenai masalah-masalah, dan isu-isu dunia nyata. Manfaat dari berpikir kritis adalah sepanjang hayat, menunjang peserta didik dalam mengatur kemampuan belajar mereka, dan kemudian memberdayakan individu untuk berkontribusi secara kreatif untuk memilih profesi yang mereka pilih nantinya.

Dengan kata lain, peserta didik yang tidak memiliki kemampuan berpikir kritis akan mudah percaya pada semua hal yang disampaikan oleh orang lain termasuk dosen/guru tanpa mempertimbangkan secara cermat, sehingga kurang mendorong peserta didik untuk lebih mengembangkan kemampuan berpikir kritisnya, selain itu tidak merubah suatu cara pandang dan pelaksanaan pembelajaran yang masih berorientasi pada pengetahuan, terikat isi, menitikberatkan pada proses pengajaran dan hasilnya mudah diukur. Berpikir kritis adalah interpretasi dan evaluasi yang terampil dan aktif terhadap proses observasi dan komunikasi, informasi dan argumentasi. Berpikir kritis akan membantu peserta didik memiliki pemikiran mengenai hal-hal yang dapat dipercaya atau yang tidak dapat dipercaya.

B. Pembahasan 


\section{Pengertian Problem Based Learning (PBL)}

Problem Based Learning merupakan model pembelajaran yang menyajikan masalah kontekstual sehingga merangsang peserta didik belajar dalam kelompok untuk memecahkan masalah dari permasalahan dunia nyata dan mengikat peserta didik pada rasa ingin tahu terhadap pembelajaran, sehingga mereka memiliki model belajar sendiri (Kemendikbud, 2014). Problem Based Learning dikenal dengan sebutan pembelajaran berbasis masalah merupakan salah satu bentuk model yang dikembangkan dari teori belajar konstruktivisme Piaget dan Vygotsky. Konstruktivisme menekankan pada pengetahuan sebagai hasil konstruksi manusia melalui interaksi mereka dengan objek, fenomena, pengalaman, dan lingkungan mereka. PBL mengembangkan ketrampilan berpikir tingkat tinggi karena melalui pembelajaran berbasis masalah peserta didik belajar menyelesaikan permasalahan dalam dunia nyata (real world problem) secara terstruktur untuk mengonstruksi pengetahuan peserta didik. Masalah sebagai titik awal pembelajaran, yang dirancang dan dipilih hendaknya memiliki kualitas dan berhubungan dengan dunia nyata peserta didik, menstimulus kemampuan kognitif, afektif, dan pskomotorik serta memungkinkan peserta didik menemukan solusi dalam diskusi kelompok bersama teman sebaya.

Model pembelajaran berbasis masalah merupakan model pembelajaran yang mengorganisasikan pembelajaran di sekitar pertanyaan dan masalah, melalui pengajuan situasi kehidupan nyata yang autentik dan bermakna yang mendorong peserta didik untuk melakukan penyelidikan dan inkuiri, dengan menghindari jawaban sederhana serta memungkinkan adanya berbagai macam solusi dari situasi tersebut (Krisna, 2013). Problem Based Learning ditandai dengan adanya kelompok-kelompok kecil, kolaboratif, proses pembelajaran dengan pendekatan ini dilakukan dengan menghadirkan masalah nyata yang kritis dan menantang dan pendekatan yang tidak hanya memfasilitasi akuisisi pengetahuan, tetapi juga meningkatkan ketrampilan komunikasi, teamwork, pemecahan masalah, kebebasan belajar, berbagi informasi, dan menghormati orang lain (Wood, 2003). Pembelajaran berbasis masalah dapat digunakan untuk memotivasi peserta didik mengidentifikasi, meneliti konsep, dan prinsipprinsip yang perlu mereka ketahui untuk belajar melalui masalah tersebut. Peserta didik bekerja dalam kelompok kecil, membawa ketrampilan bersama-sama kolektif, berkomunikasi dan mengintegrasikan informasi (Duch et al, 2001).

Berdasarkan pendapat-pendapat di atas dapat disimpulkan bahwa model Problem Based Learning (PBL) adalah suatu model pembelajaran yang menggunakan masalah dunia nyata sebagai langkah awal bagi peserta didik untuk belajar dalam mendapatkan pengetahuan dan konsep yang esensi dari setiap materi pembelajaran yang telah dimiliki peserta didik sebelumnya, sehingga terbentuklah pengetahuan yang baru. Tiga prinsip dalam pembelajaran PBL, yaitu :

a. Pembelajaran merupakan suatu proses konstruktif (learning should be a constructive process). Peserta didik aktif membangun pengetahuan mereka sendiri, memahami suatu teori berdasarkan pengalaman mereka sendiri dan juga interaksi dengan lingkungan sekitar.

b. Pembelajaran merupakan suatu proses yang dimotori oleh keinginan dari dalam 
diri sendiri (learning should be a self directed process). Peserta didik menentukan tujuan belajar mereka, kemudian mencari cara yang dapat dilakukan untuk mencapai tujuan belajar tersebut termasuk di dalamnya strategi belajar yang harus diterapkan, sumber belajar yang digunakan, apa saja kemungkinan kelemahan yang dapat menghambat dalam mencapai tujuan belajar.

c. Pembelajaran merupakan suatu proses kolaborasi (learning should be a collaborative process). Peserta didik didorong untuk berinteraksi satu sama lain, sesama anggota kelompok, peserta didik mampu membentuk suatu pemahaman baru tentang suatu permasalahan.

\section{Tujuan dan Karakteristik Problem Based} Learning (PBL)

Tujuan utama problem based learning bukanlah penyampaian sejumlah besar pengetahuan kepada peserta didik, melainkan pada pengembangan kemampuan berpikir kritis dan kemampuan pemecahan masalah dan sekaligus mengembangkan kemampuan peserta didik untuk secara aktif membangun pengetahuan sendiri (Duch, et.al, 2001). Dalam pendekatan berbasis masalah, kompleks, masalah dunia nyata digunakan untuk memotivasi peserta didik mengidentifikasi dan meneliti konsep dan prinsip-prinsip yang mereka perlu tahu untuk bekerja melalui masalah tersebut (Santika, 2018). Peserta didik bekerja dalam tim belajar yang kecil, menyatukan kemampuan kolektif yang didapat, berkomunikasi dan mengintegrasikan informasi, khususnya, kemampuan untuk melakukan hal berikut : a) berpikir kritis dan mampu menganalisa dan memecahkan masalah kompleks, dunia nyata, b) menemukan, mengevaluasi dan menggunakan sumber belajar yang tepat, c) bekerja sama dalam tim dan kelompok-kelompok kecil , d) menunjukkan ketrampilan komunikasi yang fleksibel dan efektif, lisan, dan tulisan, dan e) menggunakan konten pengetahuan dan kecerdasan ketrampilan yang diperoleh.

Karakteristik dari problem based learning yaitu :

a. Masalah atau isu-isu : titik awal pembelajaran dan aktivitas problem based learning adalah masalah atau isu yang menarik. Bidang kajian diarahkan pada masalah yang ada di lingkungan sekitar peserta didik daripada masalah yang ada dalam disiplin akademik.

b. Otentik : peserta didik mencari solusi yang realistik dengan dunia nyata dan masalah yang autentik. Masalah yang fokus pada peserta didik dan menjadi pertanyaan sosial yang penting dan nantinya peserta didik akan mendapatkan masalah yang sama dalam kehidupan.

c. Penyelidikan dan pemecahan masalah. Peserta didik dalam pembelajaran problem based learning secara aktif terlibat dalam belajar melalui penyelidikan dan pemecahan masalah daripada memproleh pengetahuan dan ketrampilan melalui mendengarkan atau membaca.

d. Pandangan interdisipliner. Peserta didik mengeksplorasi berbagai disiplin ilmu dan memberikan gambaran dari beberapa perspektif mereka ketika terlibat dalam penyelidikan problem based learning. 
e. Kolaborasi kelompok kecil. Pembelajaran terjadi dalam kelompok yang terdiri dari 56 orang anggota kelompok.

f. Produk, artefak, exhibitions, dan presentasi. Peserta didik menunjukkan hasil pembelajaran mereka dengan menciptakan produk, artefak, dan pameran. Dalam banyak kasus, mereka mempresentasikan hasil pekerjaan mereka untuk teman-teman dan tamu undangan dari kelas lain atau masyarakat.

\section{Keunggulan dan Kelemahan Problem Based}

\section{Learning (PBL)}

Keunggulan model pembelajaran problem based learning adalah : 1) merupakan teknik yang baik untuk lebih memahami isi pelajaran, 2) menantang kemampuan peserta didik serta memberikan kepuasan untuk menemukan pengetahuan baru bagi peserta didik, 3) meningkatkan aktivitas pembelajaran peserta didik, 4) membantu peserta didik mentransfer pengetahuan mereka untuk memahami masalah dalam kehidupan nyata, 5) membantu peserta didik untuk mengembangkan pengetahuan barunya dan bertanggung jawab dalam pembelajaran yang mereka lakukan.

Kelemahan model problem based learning adalah : 1) ketika peserta didik tidak memiliki minat atau kepercayaan bahwa masalah yang dipelajari sulit dipecahkan, mereka akan merasa enggan untuk mencoba, 2) keberhasilan pembelajaran melalui problem based learning membutuhkan cukup banyak waktu untuk mempersiapkan, 3) tanpa adanya pemahaman dari masalah yang dipelajari maka peserta didik tidak akan belajar apa yang mereka ingin pelajari (Hamruni, 2012).

\section{Langkah-langkah Penerapan Model Problem Based Learning (PBL)}

\begin{tabular}{|l|l|}
\hline \multicolumn{1}{|c|}{ Tahap } & \multicolumn{1}{c|}{ Keterangan } \\
\hline $\begin{array}{l}\text { Mahap 1 } \\
\text { didik terhadap masalah }\end{array}$ & $\begin{array}{l}\text { Dosen/guru menjelaskan tujuan pembelajaran dan sarana atau langkah yang } \\
\text { dibutuhkan. }\end{array}$ \\
\hline $\begin{array}{l}\text { Tahap 2 } \\
\text { Mengorganisasi peserta didik } \\
\text { untuk belajar }\end{array}$ & $\begin{array}{l}\text { Dosen/ guru membantu peserta didik mendefinisikan dan mengorganisasi } \\
\text { tugas belajar yang berhubungan dengan masalah yang sudah diorientasikan } \\
\text { pada tahap sebelumnya. }\end{array}$ \\
\hline $\begin{array}{l}\text { Tahap 3 } \\
\text { Membimbing penyelidikan } \\
\text { individual maupun kelompok }\end{array}$ & $\begin{array}{l}\text { Dosen/guru mendorong peserta didik untuk mengumpulkan informasi yang } \\
\text { sesuai dan melaksanakan eksperimen untuk mendapatkan kejelasan yang } \\
\text { diperlukan untuk menyelesaikan masalah. }\end{array}$ \\
\hline $\begin{array}{l}\text { Tahap 4 } \\
\text { Mengembangkan dan } \\
\text { menyajikan hasil karya }\end{array}$ & $\begin{array}{l}\text { Dosen/guru membantu peserta didik untuk berbagi karya/tugas dan } \\
\text { merencanakan karya yang sesuai dengan hasil pemecahan masalah dalam } \\
\text { bentuk laporan. }\end{array}$ \\
\hline $\begin{array}{l}\text { Tahap 5 } \\
\text { Menganalisis dan } \\
\text { mengevaluasi proses } \\
\text { pemecahan masalah }\end{array}$ & $\begin{array}{l}\text { Dosen/guru membantu peserta didik untuk melakukan refleksi atau evaluasi } \\
\text { terhadap proses pemecahan masalah yang dilakukan. }\end{array}$ \\
\hline
\end{tabular}


(Sumber : Nur, 2011)

\section{Potensi Pembelajaran Problem Based Learning (PBL) dalam Melatih} Kemampuan Berpikir Kritis Peserta didik Model pembelajaran problem based learning (PBL) memiliki dua karakter dasar yag berkaitan yaitu karakter dalam PBL sendiri yang akan memunculkan karakter metakognitif. Pada pembelajaran PBL berpusat pada peserta didik. Pada pembelajaran ini menuntut peserta didik aktif dan kolaboratif dalam pembelajaran, sehingga mampu mengembangkan kemampuan pemecahan masalah secara mandiri. Fokus pembelajaran ini ada pada masalah yang dipilih sehingga peserta didik tidak saja mempelajari konsep-konsep yang berhubungan dengan masalah tetapi juga metode ilmiah untuk memecahkan masalah tersebut. Peserta didik tidak saja harus memahami konsep yang relevan dengan masalah yang menjadi pusat perhatian tetapi juga memproleh pengalaman belajar yang berhubungan dengan ketrampilan menerapkan metode ilmiah dalam pemecahan masalah dan menumbuhkan pola berpikir kritis.

Metakognisi adalah sebagai proses dimana seseorang berpikir tentang berpikir dalam rangka membangun strategi untuk memecahkan masalah. Pengetahuan metakognisi adalah pengetahuan tentang kognisi, secara umum sama dengan kesadaran dan pengetahuan tentang kognisi diri seseorang. Dapat dikatakan bahwa metakognisi merupakan kesadaran tentang apa yang diketahui dan apa yang tidak diketahui. Strategi metakognisi merujuk kepada cara untuk meningkatkan kesadaran mengenai proses berpikir dan pembelajaran yang berlaku sehingga bila kesadaran ini terwujud maka seseorang dapat mengawal pikirannya dengan merancang, memantau, dan menilai apa yang dipelajarinya. Sedangkan karakter metakognitif melibatkan tiga macam pengetahuan : 1) pengetahuan deklaratif tentang diri sebagai pembelajar, 2) pengetahuan prosedural atau tahu bagaimana menggunakan strategi, dan 3) pengetahuan kondisional untuk memastikan penyelesaian tugas-tugas dengan menerapkan prosedur dan strategi.

Proses berpikir juga merupakan suatu kegiatan mental yang disadari dan diarahkan untuk maksud dan tujuan tertentu (Santika, 2020). Maksud yang dicapai dari berpikir selain untuk membangun dan memperoleh pengetahuan, juga untuk mengambil keputusan, membuat perencanaan, memecahkan masalah, serta untuk menilai tindakan. Dalam proses berpikir termuat kegiatan meragukan dan memastikan, merancang, menghitung, mengukur, mengevaluasi, membandingkan, menggolongkan, memilah-milah atau membedakan, menghubungkan, menafsirkan, melihat kemungkinan-kemungkinan yang ada, menganalisis sintensis, menalar atau menarik kesimpulan dari premis yang ada, menimbang dan memutuskan. Kemampuan berpikir kritis menjadi kemampuan yang sangat diperlukan agar peserta didik sanggup menghadapi perubahan keadaan atau tantangan-tantangan di dalam kehidupan yang selalu berkembang. Kemampuan berpikir kritis sangat penting untuk peserta didik, karena kemampuan berpikir yang rendah ini berdampak pada hasil belajar peserta didik juga rendah. Indikator rendahnya kemampuan berpikir kritis peserta didik dapat teramati dari kurangnya kemampuan bernalar peserta didik dalam pemecahan masalah. 
Dengan digabungkannya model pembelajaran PBL (problem based learning) yang didukung dengan strategi metakognitif dapat mengasah kemampuan peserta didik untuk berpikir kritis dan diharapkan kemampuan ini semakin meningkat. Model pembelajaran PBL, dalam memecahkan suatu permasalahan dalam kegiatan belajarnya membutuhkan ketrampilan-ketrampilan metakognitif dalan mengidentifikasi masalah. Dengan disajikannya sebuah masalah, peserta didik dituntut untuk menggali segala pengetahuan yang dia miliki kemudian memanajemen pengetahuan atau informasi tersebut, memilah informasi atau pengetahuan mana yang dibutuhkan untuk memecahkan masalah. Dengan hal tersebut peserta didik secara tidak langsung belajar mengasah kemampuan berpikirnya menjadi lebih tajam, dan dengan tuntutan-tuntutan tersebut peserta didik menjadi terampil dan kreatif dalam mengatasi berbagai masalah yang mereka hadapi.

\section{Penerapan Model Problem Based Learning}

(PBL) dalam Pembelajaran

Berikut adalah kegiatan pemanfaatan model problem based learning yang terdiri dari tahapan pendahuluan, inti dan penutup.

a. Pendahuluan

Pada tahapan ini dilakukan tahap I dalam sintaks PBL, yaitu mengorientasi peserta didik pada masalah. Masalah tersebut dapat disajikan dalam bentuk gambar, film pendek, atau dalam tampilan power point. Dalam hal ini, peserta didik mencermati sajian masalah, guru mengajukan pertanyaan untuk mendorong peserta didik memprediksi atau mengajukan dugaan/ hipotesis dari kasus atau masalah yang diberikan.

b. Inti
Mengorganisasikan peserta didik untuk belajar (tahap 2) melalui kegiatan tanya jawab (menanya) dengan dosen/guru mengingatkan kembali langkah-langkah atau metode ilmiah. Dosen/guru mengorganisasi peserta didik untuk belajar dalam kegiatan diskusi kecil. Membimbing peserta didik secara individual atau kelompok dalam merancang eksperimen untuk menguji hipotesis dan rancangan eksperimennya untuk mendapatkan saran dari kelompok lain.

Membimbing penyelidikan individual maupun kelompok (tahap 3) dengan memberikan bimbingan kepada peserta didik untuk melakukan penyelidikan atau eksperimen. Bimbingan tersebut meliputi pengumpulan informasi yang berkaitan dengan materi yang diangkat dalam permasalahan. Kemudian kelompok peserta didik melakukan eksperimen berdasarkan rancangan yang telah mereka buat dengan bimbingan guru.

Mengembangkan dan menyajikan hasil karya (tahap 4). Peserta didik hasil penelitian sesuai format yang telah disepakati. Kelompok terpilih mempresentasikan hasil eksperimen dan kelompok lain menanggapi. Menganalisis dan mengevaluasi proses pemecahan masalah (tahap 5).

c. Penutup

Dengan bimbingan dosen/guru, peserta didik menyimpulkan hasil diskusi. Dosen/guru dapat melakukan kegiatan pengayaan dan remidi.

\section{Penutup}

\section{Simpulan}

Problem based learning (PBL) adalah suatu pendekatan yang menggunaka masalah 
dunia nyata sebagai suatu konteks bagi peserta didik untuk belajar tentang cara berpikir kritis dan ketrampilan pemecahan masalah serta untuk memproleh pengetahuan esensial dari materi pelajaran. Problem based learning merupakan salah satu model pembelajaran yang menuntut aktivitas mental siswa untuk dapat memahami suatu konsep pembelajaran melalui situasi dan masalah yang disajikan pada awal pembelajaran dengan tujuan untuk melatih peserta didik menyelesaikan masalah dengan menggunakan pendekatan pemecahan masalah. Model ini juga dapat mengembangkan kemampuan berpikir siswa, melatih ketrampilan memecahkan masalah dan meningkatkan penguasaan materi pelajaran. Hal ini karena PBL diterapkan untuk merangsang berpikir tingkat tinggi dalam situasi berorientasi masalah, termasuk di dalamnya belajar bagaimana belajar.

\section{Daftar Pustaka}

Daryanto. (2014). Pendekatan Pembelajaran Saintifik Kurikulum 2013. Yogyakarta : Gaya Media.

Darwati, Mas \& Mahendra, Putu Ronny Angga. (2019). Efektivitas Pembelajaran PPKn Berbasis Teknohumanistik Dalam Pembentukan Karakter Siswa Kelas X Jasa Boga 2 SMK Prshanti Nilayam Kuta Tahun Pelajaran 2017/2018. Singaraja: FHIS Universitas Pendidikan Ganesha.

Duch, B.J. et al. (2001). The Power of Problem Based Learning. Sterling : Stylus Publishing.

Emi Rofiah, dkk. (2018). Pengembangan Modul Pembelajaran IPA Berbasis High Order Thinking Skill (HOTS) Untuk Meningkatkan Kemampuan Berpikir Kritis Siswa Kelas
VIII SMP/MTs. Jurnal Pendidikan IPA Vol. 7 No. 2 Universitas Sebelas Maret.

Falwi Uji Flamboyan, dkk. (2018). Pengaruh Model Based Learning Terhadap High Order Thinking Skills Peserta Didik SMA Negeri di Kota Singkawang pada Materi Hukum Archimedes. Jurnal Variabel Vol. 1 No. 2 STKIP Singkawang.

Farida, dkk. (2015). Potensi Sintaks Pembelajaran Problem Based Learning Metakoginitif Dalam Melatih Kemampuan Berpikir Kritis Siswa. Seminar Nasional Pendidikan Sains. Universitas Kristen Satya Wacana.

Hamruni. (2012). Strategi Pembelajaran. Yogyakarta: Insan Madawi.

Kartika, I. M., Angga Mahendra, P. R., \& Awa, V. (2021). Penerapan Pembelajaran Problem Based Learning untuk Meningkatkan KetrampilanBerpikir Kritis Siswa Pada Mata Pelajaran PPKn. Jurnal Locus Delicti, 1(1), 1-10. Retrieved from https://ejournal2.undiksha.ac.id/index.php/J LD/article/view/187

Santika, I. G. N., Sujana, G., \& Winaya., M. A. (2019). Membangun Kesadaran Integratif Bangsa Indonesia Melalui Refleksi Perjalanan Historis Pancasila Dalam Perspektif Konflik Ideologis. Jurnal Etika Demokrasi (JED). 4 (2), 89-98. https://doi.org/10.26618/jed.v4i2.2391

Krisna, Evi Dwi, dkk. (2013). Pengaruh Model Pembelajaran Berbasis Masalah Berbantuan Pertanyaan Metakognitif Terhadap Prestasi Belajar Matematika Siswa Ditinjau Dari Motivasi Berprestasi. E-journal Program Pascasarjana Universitas Pendidikan Ganesha Program Studi Matematika. 2:1-11.

Mahendra, Putu Ronny Angga. Pembelajaran PPKn dalam Resonansi Kebangsaan dan Globalisasi. Jurnal Ilmiah Ilmu Sosial. Singaraja : Universitas Pendidikan Ganesha.

Mahendra, Putu Ronny Angga. Memperkuat Kesadaran Bela Negara Dengan Nilai-Nilai Pancasila Dalam Perspektif Kekinian. Jurnal Pendidikan Kewarganegaraan. Singaraja : Universitas Pendidikan Ganesha. 
Mira, Safrida., dkk. (2020). Penerapan Model Pembelajaran Problem Based Learning (PBL) Untuk Meningkatkan Hasil Belajar IPA Kelas V SD Negeri Peureumemume Kecamatan Kaway XI. Jurnal Bina Gogik Vol. 7 No. 1.

Nur, M. (2011). Pembelajaran Berbasis Masalah. Surabaya : PSMS Unesa.

Rahmayanti, Esty. (2017). Penerapan Problem Based Learning dalam Meningkatkan Kemampuan Berpikir Kritis Peserta Didik pada Pembelajaran Pendidikan Pancasila dan Kewarganegaraan Kelas XI SMA. Prosiding Konferensi Nasional Kewarganegaraan III Universitas Ahmad Dahlan Yogyakarta.

Santika, I Gusti Ngurah. (2017). Kepala Sekolah Dalam Konsep Kepemimpinan Pendidikan: Suatu Kajian Teoritis. Widya Accarya. 7 (1).

Santika, I. G. N. (2020). Menggali dan Menemukan Roh Pancasila Secara Kontekstual. Jawa Tengah: Lakeisha.

Santika, I. G. N. (2020). Optimalisasi Peran Keluarga Dalam Menghadapi Persoalan Covid-19: Sebuah Kajian Literatur. Jurnal Ilmiah Ilmu Sosial. 6 (2), 127-137. http://dx.doi.org/10.23887/jiis.v6i2.28437

Santika, I. G. N. (2018). Strategi Meningkatkan Kualitas SDM Masyarakat Desa Padangsambian Kaja Melalui Pendidikan Karakter Berbasiskan Kepedulian Lingkungan Untuk Membebaskannya Dari Bencana Banjir. Widya Accarya. 9 (2).

Subandiyah, Heny, dkk. (2010). Model Pembelajaran Berdasarkan Masalah (Problem-Based Instruction).

Sudarman. (2007). Problem Based Learning: Suatu Model Pembelajaran untuk Mengembangkan dan Meningkatkan Kemampuan Memecahkan Masalah. Jurnal Pendidikan Inovatif Vol.2 No.2 Maret 2017.

Tomi Utomo, Dwi Wahyuni dan Slamet Hariyadi. (2014). Pengaruh Model Pembelajaran Berbasis Masalah (Problem Based Learning) Terhadap Pemahaman Konsep dan Kemampuan Berpikir Kreatif Siswa (siswa Kelas VIII Semster Gasal SMPN 1 Sumbermalang Kabupaten Situbondo Tahun Ajaran 2012/2013). Jurnal Edukasi UNEJ 2014,I (1) : 5-9.

Wood, D.F. (2003). ABC of learning and teaching in medicine: Problem Based Learning. Clinical review: BMJ Volume 326. 